\title{
DETECting the "Noirification" of European Popular Narratives Across Film, Fiction and Television
}

\section{Federico Pagello}

\begin{abstract}
The article explores the transcultural dimension of European crime narratives by looking at the specific role of cinema in this context. Building on the research conducted by DETECt scholars in different areas of contemporary popular culture-especially literature and television-it first discusses the link between the more and more widespread use of the "noir" label and the increasing cultural legitimation of the crime genre. The article then argues that this phenomenon echoes the emergence of a new "European quality crime film" in recent years. While stressing the potential contribution of the genre to the circulation of European cinema, the evident limits of its impact in this field are also examined. Finally, it looks more closely at the transnational circulation of contemporary Italian crime films to assess to what extent they have been able to find a transnational audience on a continental level. In this context, the importance to look beyond theatrical distribution and the centrality of intermedial exchanges are highlighted, indicating new directions for research.
\end{abstract}

Is the increasing transnational dimension in the production, distribution and consumption of popular narratives helping to shape new European transcultural identities, or does it reveal the persistent cultural fragmentation and sociopolitical conflicts characterising Europe's past and present? The research conducted in the frame of the DETECt project, from which this article originates, addresses this question by looking at the case of crime narratives, arguably the most successful, adaptable and enduring narrative genre in modern popular culture. ${ }^{1}$ Drawing on previous research projects on the role of popular media in the process of European integration (Agger; Bondebjerg and Redvall; Bondebjerg et al.), as well as on a growing body of scholarship on the transcultural and transnational dimension of contemporary crime narratives (Damrosch, d'Haen and Nilsson), DETECt examined whether and how this genre has contributed to making "mediated cultural encounters" possible among different communities and individuals across the continent that facilitate the "banal Europeanisation" of the everyday experiences of millions of people (Bondebjerg et al. 4). This article builds on DETECt's specific interest in the relationships among different media-literature, cinema and television - with the goal of assessing the particular role of crime films in this broader, intermedia context. In particular, the article argues that to study the transnational circulation of European crime cinema it is necessary to think of the genre as an inherently intermedial phenomenon, in which the success of discrete texts is less significant than the complex network of relationships in which they are included.

The first section examines the role of the crime genre-and especially noir -in facilitating the emergence of new transcultural phenomena in European popular culture, especially in the fields of literature and television, discussing how the link between the genre and discourses about "quality" has become increasingly crucial for the transnational circulation of European popular narratives. The second section focuses on the field of cinema, engaging with scholarly analyses of the production and distribution of European crime films, which 
highlight the emergence of a new category: the "quality crime film" (Baschiera). In the third and final section I examine how the transnational circulation of Italian crime films perfectly illustrates this phenomenon, emphasising the centrality of intermediality in this trend.

\section{"Euro Noir"? On the Noirification of European Popular Narratives}

The DETECt project examined how the vast and in-depth circulation of popular crime narratives in Europe as well as elsewhere has facilitated the emergence of various glocal and transcultural phenomena, asking whether they can provide the opportunity for European creatives and audiences to identify as members of the same "imagined community", which would make its European dimension apparent and could be embraced by individuals as well as groups across the continent. One way in which DETECt scholars have addressed this issue has been to examine the increasingly widespread use of labels such as "Nordic Noir", "Mediterranean Noir" or "Euro Noir" to highlight the transnational and, often, properly transcultural dimension of these phenomena (Baetens, Schultze and Truyen; Baetens and Truyen; Dall'Asta, Levet and Pagello; Biscarrat and Jacquelin). As scholars have widely discussed, Nordic Noir has become a paradigmatic example not only of the ability of the (multination) Scandinavian region to acquire a recognisable identity and to export its products across Europe and beyond, but also of the ability of this specific kind of crime narratives to influence the approach to the genre in many other parts of the continent, thus eliciting the emergence of new, hybrid cultural production (Creeber; Hansen, Peacock and Turnbull; Hansen). DETECt scholars Sándor Kalai and Anna Keszeg have shown this process very clearly in their study of what has been called, quite paradoxically, "Hungarian Nordic Noir". In a rather different way, the case of Mediterranean Noir has already provided ample evidence for the properly transcultural dimension of the crime narratives produced in the Southern part of the continent (Turnaturi). Focusing our attention on the cultural and ethnic diversity of this particular context, DETECt scholars highlighted that these crime narratives do not only cross national borders, but also Europe's geographical boundaries, thus questioning any simplistic assumptions about how we think about European cultural identity (Pepper; Pezzotti).

Also for this reason, DETECt scholars started to use the label "Euro Noir" to signal, rather than the existence of a homogenous phenomenon, that of a set of texts, trends, and questions indicating the increasingly interconnected relationships among popular narratives produced in different countries as well as different media across Europe. Interestingly, the term was first proposed by the British journalist and cultural critic Barry Forshaw in his Euro Noir: The Pocket Essential Guide to European Crime Fiction, Film \& TV, a book that in spite of its title adopts a national perspective on its subject matter to explicitly emphasise the diversity and richness of the approaches found in each European country. DETECt literary scholars, however, started to adopt this label in studies focusing on the transnational circulation of European crime novels (Migozzi; Biscarrat and Jacquelin) and their common generic and cultural identity (Baetens; Baetens and Truyen). Looking at how the work of writers such as Fred Vargas, Andrea Camilleri, Jo Nesbo, Petroks Markaris and many others has been widely translated across the continent, Migozzi indeed argued that it is possible to identify a specific moment - between the late 1990s and the early 2000s — when literary markets across Europe opened up their doors to a much richer exchange of authors and stories from different European countries, reducing the traditional (Anglo-)American domination and promoting mutual exchange among the various national schools in the Old Continent. "Euro Noir", in this sense, becomes a label for this transnational and increasingly transcultural genre that results from the mutual influences among writers working in different parts of the continent. 
A similar process has recently also become apparent in the field of television, in which European crime dramas have quickly transformed in order to address the competition of the new, American "quality" series (Pagello, "Images"). As Kim Toft Hansen (a member of DETECt project), Steven Peacock and Sue Turnbull have argued, the success of Nordic Noir in this medium was just the first and clearest sign of how European crime TV dramas started to receive larger visibility on continental as well as global distribution platforms (2). This process has led to the development of a range of new strategies for the production and circulation of TV series and enriched the traditionally national dimension of European television and, particularly, PSBs. During the last decade, transnationally successful crime series were produced in countries such as France, Italy, Germany, Spain, the Netherlands, Belgium, Hungary, Romania and Poland, while the activities of (American) multinational corporations such as Sky, Netflix and HBO Europe have greatly increased the opportunities for audiences to access a variety of non-domestic European series that were previously inaccessible. The success of shows such as Peaky Blinders (BBC2/BBC1, 2013-), The Returned (Les Revenants, Canal+, 2013-2015), Gomorra (Sky, 2014-), Money Heist (La casa de papel, Antena 3/Netflix, 2017), Babylon Berlin (Sky, 2017-), and Dark (Netflix, 20172020) has not only proven the enhanced opportunities for European series to reach a truly continental audience, but have also offered stimulating representations of European society, history and current socio-political climate, using the crime genre and/or some of its stylistic features in varied ways (Dall'Asta, Levet and Pagello). This phenomenon has thus led DETECt scholars to suggest the label "Euro Noir" could cautiously be adopted to highlight not only the continental scale of these phenomena, but also their common features and ability to represent, and speak to, the shared experience of viewers across the continent (Hansen; Kalai and Keszeg; Dobrescu).

To fully apprehend the nature of this trend, however, we should turn our attention not only to its European dimension, but also to the specific role of the crime genre, and particularly of noir. The literary and TV crime narratives mentioned above have been indeed regularly associated, even if sometimes perhaps arbitrarily, with one (or more) variants of this subgenre. In addition to the "Nordic", "Mediterranean" and "Euro" variants, labels such as "regional noir", "country noir" or "rural noir" have been used more and more often to describe the use of the genre to explore special space and socio-cultural context (Jacquelin), while local and national "schools" such as "Tartan Noir", "Italian noir", "Belgian Noir", "Novela negra" and so on have acquired a continental and sometimes global resonance. But what is the contribution that such labels give to the circulation of crime novels and TV series on a transnational level? As literary and TV scholars have already suggested (Gorrara; Pieri 4; Steenberg), this article argues that the reference to noir genre is aimed at providing crime narratives with a "quality" status able to support the translation, adaptation and promotion of non-national cultural products in other European countries.

The phenomenon first became visible in the field of literature. While long regarded as a popular pastime with scarce literary credentials, and with little or zero cultural capital, crime novels have become since the 1980s the object of a deep critical re-evaluation. ${ }^{3}$ After moving rapidly from the fringes of literature to the very centre of the contemporary publishing industry, the genre then acquired through the process of adaptation an increasingly important role in a growingly interconnected media system that currently finds its most powerful distribution channel in contemporary digital television. It is precisely in this context that European publishers, critics and audiences first started to identify - and to promote for an international audience - the novels written by authors as diverse as Jean-Pierre Manchette, Ian Rankin, Carlo Lucarelli, Jean-Claude Izzo, Andrea Camilleri, Fred Vargas, Hennik Mankell with the label of 
"noir"- perhaps not despite but because the term has always been disputed and, in some of these cases, might not even be entirely pertinent. As shown by literary and media scholars (Mondello; Jansen, Lanslots and Vermandere), during the 1990s authors and publishers more consciously embraced the brand "noir" both as a literary and a marketing strategy in order to differentiate their output from the mass of crime narratives. In particular, noir's tendency to abandon some of the features of classical detective fiction to focus on social criticism, a darker representation of reality and a greater emphasis on the characters and the settings of the stories - rather than simply on the plot-have been regularly stressed to provide these narratives with a patent of cultural legitimacy (Jansen, Lanslots and Vermandere 9).

As is well known, the very same process has been at the centre of contemporary TV crime series, for instance in the crucial case of the promotion and reception of Nordic Noir (Hill and Turnbull). Here, the noir label helped to articulate a discourse about contemporary "quality" TV dramas as something different from "simple" crime series, emphasising the subgenre's association with social critique, existentialist mood, elaborate stylistic strategies, multi-layered storylines and sombre antiheroes. In recent years, neo-noir-or "noirised"series have been now regularly used by all kinds of television producers and commissioners (public and private broadcasters, pay-TVs, OTTs) to compete in the increasingly crowded, but also appealing, market of transnational digital television. In the last decade this change has perhaps been even more evident in Europe than elsewhere, since the arrival of new players such as Sky, Netflix, Amazon or HBO has deeply transformed the production and distribution of scripted programmes, in particular by opening up a new international market for European TV series. Following the most influential American quality television series-from The Sopranos (HBO, 1999-2007) to True Detective (HBO, 2013-), from Dexter (Showtime, 20062013) to Ozark (Netflix, 2017-), from Breaking Bad (AMC, 2008-2013) to Fargo (FX, 2014) - an impressive percentage of the most successful European TV series have explicitly drawn on noir or neo-noir elements for their characters, stories, setting and/or style. Shows as diverse as the aforementioned The Killing, Peaky Blinders, Babylon Berlin, Money Heist and even the more classical Sherlock (BBC, 2010-) have been associated with the genre one way or another, as they effectively used the neo-noir elements to connect with these larger trends in international television. As clearly argued by Lindsay Steenberg, these series are received by the audiences, journalists and critics as "complex, realist, and significant" precisely because

the noir filter is a very successful legitimation strategy. It is a mobilization of the tropes, aesthetics, and cultural myths circulating around film noir to call upon a history of critical acclaim and debate. The act of labelling something noir, particularly a visual fiction, is a way of insisting on its status as art. (62)

The recent phase in the history of European crime narratives and, particularly, in their transnational circulation is thus deeply linked to the "re-branding" of the genre as something other than classic crime fiction, which seemed to have exhausted at least some of its potential and could survive only through a renewal that took the form of its "noirification". This term has been proposed by the Italian scholar Massimo Locatelli in his monograph on contemporary crime narratives, Psicologia di un'emozione. Thriller e noir nell'età dell'ansia, to indicate the widespread adoption by popular narratives across media of the themes, atmospheres, and stylistic features of noir, often in combination with other genres. Locatelli provides a variety of examples, referring to literature, film, comics and television series, embracing dramatic and comedic texts, art cinema and Hollywood franchises, children's stories and adult-only imagery. Of course, this spread and contamination also necessarily involved a weakening of the genre's, already notoriously precarious, borders and further increased the proliferation of hybrid texts, 
in which noir is only one of the elements and, often, not the most important. Precisely for this reason, however, I believe that "noirification" is a useful concept to illustrate how, while the "quality" of these "noirised" texts has been constantly questioned, this label has been widely adopted by producers, distributors and consumers to discuss these narratives and their transnational success.

\section{European Crime Film Between Auteur and Quality Cinema}

If the process of legitimisation and increasing transnational circulation has been so clear in the field of fiction and television, what happened in the field of European cinema, whose cultural capital and industrial system is certainly significantly different? To answer this question is not so straightforward: while DETECt scholars could benefit from the large scholarship that has been produced during the last decades on European crime novels and TV series, the situation in the field of film studies is largely different. In fact, studies on crime cinema that adopt a European perspective are extremely rare (Spicer), as scholars have tended to focus instead on specific historical periods, authors or national schools. In fact, it is possible to argue that research on European crime cinema is an underdeveloped field of study, and that neither its transnational or popular dimensions have received sufficient attention. Confirming well-established notions about the absence of a truly European popular cinema (Dyer and Vincenceau; Eleftheriotis), as well as the impression that European crime film has mostly developed on a national level (Spicer), DETECt scholars did find it difficult to identify comparable trends to those observed in other media.

In fact, DETECt's contribution to this field has been so far comparatively scarce and its most significant output-Stefano Baschiera's article "European Crime Cinema and the Auteur"-emphasised the limited effort by European industries to invest in the production and promotion of popular crime films on a continental level. In particular, the issue does not seem to concern the lack of European crime films but rather their specific characteristics and the difficulties regarding their transnational circulation:

the landscape is still dominated by comedies, grossing well at the local level, and heritage films, including nostalgia and historical films [...] the role of crime films is still marginal and of difficult categorisation, underlying more the permeability between art-house and mainstream (in a way not dissimilar from middlebrow productions like heritage or historical films) than presenting a clear generic identity. This is even more relevant considering the move away from the national context to consider a European approach. While there are examples of genrefication at the national level (from German's krimis to French polar and Italian mafia films) it is also true that those phenomena are increasingly rare in contemporary European cinema. (Baschiera 5)

In fact, despite the existence of numerous individual cases of critically acclaimed and commercially successful European crime films on a transnational level in the last few yearsfrom In Bruges (Martin MacDonagh, 2008) to The Girl With a Dragon Tatoo (Män som hatar kvinnor, Niels Arden Oplevl, 2009), from A Prophet (Un prophète, Jacques Audiard, 2013) to Victoria (Sebastian Schipper, 2015) — the auteurist brand as a necessary tool to obtain visibility beyond the domestic borders continues to play a crucial role. Moreover, the traditional association of European crime cinema to national schools or subgenres primarily addressed to 
a domestic audience and/or to a limited niche of cinephiles makes it difficult for this type of film to address a truly continental audience on a regular basis.

In this sense, Baschiera's article seems to confirm previous studies that have emphasised not only the limited circulation of European crime films but also strong links to specific cultural contexts. This was indeed a main argument of the important collection of essays European Film Noir edited by Andrew Spicer in 2007, which emphasised how the identification of European cinema with art cinema and the specificities of the different national contexts have left their visible marks on this genre. As with the case of Forshaw's Euro Noir, Spicer's collection is indeed organised in sections that strictly refer to national areas (France, Great Britain, Germany, Spain and Italy), each emphasising their specificity and relative autonomy:

The aspect of European film noir that emerges most strongly from this survey is its national specificity. In each country, noir and neo-noir have individual trajectories that reflect that nation's history, its political organisation, its cultural traditions, the state of its film industry and the strengths of its cinematic culture. In each case, film noir and neo-noir frequently engage with social, political and cultural issues that are particular to that nation. This leads to marked variations in characterisation and in the construction of gender. There are also significant differences in visual style and aesthetics between the various countries, and also a wide variety within each separate national noir/neo-noir. (13-14)

European Film Noir furthermore shows how the role of auteurs is also evident by presenting stylistic and thematic readings that highlight the aesthetic and cultural approaches adopted by European crime films, without taking into consideration their international circulation and their possible mutual influences. In fact, in his introduction to the book, Spicer explains how all these different European cinemas negotiate their identity primarily through their relationship to the model of American noir, effectively giving shape to a proper transnational and, his in words, "transcultural" phenomenon which, however, is generated through their common references to this external party rather than a direct connection to each other (17).

While the mediation of Hollywood cinema is also stressed by Baschiera (5), his study takes us a little further, helping us identify both a new emerging trend and a different analytical perspective that can shed light on aspects that would be otherwise underestimated. Perfectly in line with the larger context discussed by DETECt scholars, Baschiera highlights how an exclusive focus on the relationship to American cinema implies "a missed opportunity to create the kind of links, connections and transnational influences which would allow an understanding and a conceptualisation of crime film as part of a European popular cinema" (9). On the contrary, Baschiera suggests giving more attention on the idea of the recent emergence of a European "quality" crime film, which he defines as "commercial productions with auteurist ambitions" and whose existence he links to the increasingly central role played by national broadcasters in the European film production (5). ${ }^{4}$

As we will see in relation to the case of Italian cinema, discussed in the next section, this development has helped recent European crime films to find an international distribution, even if it often reaches only a small audience. While this phenomenon remains marginal, it suggests that we are witnessing a convergence of film industrial and aesthetic practices with the larger trends discussed above. Moreover, the centrality of intermedial relationships is 
directly linked to the opportunity for contemporary cinema to take advantage of a potentially global online distribution, which not only transcends national borders much more easily, but also emphasises the necessity of thinking about film as a specific area of an interconnected media system.

\section{On the Theatrical Distribution of Italian Crime Films}

In what follows, I will examine in particular information acquired from the International Movie Database (IMDb) and the European Audiovisual Observatory's LUMIERE database to offer both a quantitative and qualitative assessment of this phenomenon. On the one hand, although IMDb's categorisation must not be regarded as an objective classification about Italian film production, I suggest that an analysis of its labelling of Italian films can help us identify some significant clues about their international reception, as concerns both their visibility outside of the country and the way in which distributors and audiences think about "Italian crime cinema". On the other hand, by looking at the LUMIERE data about the number of admissions for Italian crime films across Europe, I will examine how the films that have obtained at least some theatrical distribution on a continental level show the clear impact of the transnational and intermedial trends that I have discussed in the first part of this article, supporting the idea that we are witnessing the gradual emergence of a new, European approach to the genre also in the field of cinema.

As regards the specific period taken into consideration by the DETECt project-from 1989 to the present - IMDb provides the titles of around 290 Italian feature films tagged with the label "crime". ${ }^{5}$ What this corpus makes immediately clear is that a large percentage of these titles do not actually refer to genre films or, in many cases, that their main generic features do not fall within the crime genre. In most cases these films are examples of auteur cinema or social, political or historical dramas or comedies that include - and, sometimes, focus on - a variety of criminal activities and events, often anchored in Italy's reality: as a matter of fact, these films incorporate or touch upon elements of the crime genre but do not resolutely adopt the well-established conventions of crime narratives. In this sense, the IMDb corpus confirms the idea that many Italian "crime" films engage with crime more as a thematic element than as a genre informing the films' narrative structures or stylistic features, thus echoing the scholarly analyses about the superimposition of art cinema and the crime genre discussed in the previous section. By looking at the IMDb list, in fact, it is possible to argue that such an approach is not limited to the films that aim to obtain an international audience, but it is common to the majority of Italian "crime" films.

If we then look at the data collected by the European Audiovisual Observatory's LUMIERE database about the admissions to Italian films in theatres across the continent, we verify how the number of films from the IMDb list that actually received at least some international attention is surprisingly limited, and that their box office results are rather disappointing. In fact, less than ten per cent of the films labelled by IMDb as "crime" seem to have reached more than a few thousand viewers through their theatrical distribution outside of the country. According to the LUMIERE database, which has collected such data since 1996, only nine of these films have sold more than 100,000 tickets in the European region (including Russia), and only twenty-four sold more than 10,000 tickets throughout the last twenty five years (see Table 1). While bearing in mind the biases in IMDb's categorisation system and its extremely broad definition of the notion of "crime film", these figures prove that the transnational circulation of Italian "crime" films, at least as concerns their theatrical 
distribution, is extremely limited, if not non-existent. The following considerations aim therefore to show that, in spite of such small absolute numbers, these films participate in a much wider network of exchanges in the fields of fiction and television and that they both benefit to a certain extent from the emergence of a transnational popular culture on a continental level. Of course, it is also necessary to consider that Italian crime films could be now potentially distributed through a variety of digital platforms, which would provide the opportunity for a much more extensive and extended exposure to transnational audiences. ${ }^{6}$ It is precisely through these different channels of distribution that the intermedial dimension of European crime cinema might fully emerge in the future, emphasising how crime films are actually part of much broader narrative worlds that European viewers and readers might encounter in a variety of media contexts.

If we look more closely at the shortlist in Table 1, the analysis of European crime cinema described in the previous section seems indeed to be confirmed. Almost all of these films combine the themes or some of the stylistics features typical of the crime genre with clear markers of an authorial brand, literary credentials and/or an explicit engagement with the national history or contemporary social reality. Films such as One Hundred Steps (I cento passi, Marco Tullio Giordana, 2002), The Consequences of Love (Le conseguenze dell'amore, Paolo Sorrentino, 2004), My Brother Is an Only Child (Mio fratello è figlio unico, Daniele Lucchetti, 2007), Gomorrah (Gomorra, Matteo Garrone, 2008), Human Capital (Il capitale umano, Paolo Virzì, 2013), Black Souls (Anime nere, Francesco Munzi, 2014), Dogman (Matteo Garrone, 2018) or The Traitor (Il traditore, Marco Bellocchio, 2019) are indeed primarily auteur films and/or socio-political dramas, sometimes adapted from literary sources and, specifically, from the work of writers dealing with criminal facts - often based on real events - as opposed to novels written by crime-fiction specialists. While their real or supposed links to the crime genre should not be underplayed, especially when thinking about their box-office results in the domestic market, these films certainly did not obtain an international distribution because of their potential generic identity, but rather as a result of the cultural capital as well as the commercial value attached to these other features. It is indeed no coincidence that eight of the first ten films in this list premiered at international film festivals such as Cannes or Berlin, more than half received major national and international prizes (including the European Film Awards) and, above all, most of them were signed by some (if not almost all) of the main contemporary Italian directors. ${ }^{7}$

Besides this superimposition of the authors' brand and the crime genre, however, other characteristics of these films become immediately visible by adopting the intermedial perspective discussed above. Half of the titles in this list, and seven in the first ten, are adaptations from literary sources (I include in this category Saviano's Gomorrah, despite its non-fictional topic). In the cases of Romanzo criminale (Michele Placido, 2005), Gomorrah, Suburra (Stefano Sollima, 2015) and Piranhas (La paranza dei bambini, Claudio Giovannesi, 2019), then, we are dealing with adaptations of books, by authors such as Saviano and De Cataldo (the latter one of the most successful contemporary Italian crime writers), that had already obtained international fame and that were soon to be turned into even more popular TV series. Part of truly cross-media crime narratives, these films build on pre-sold properties in order to aim for an international audience (Boni; Benvenuti; Guerra, Martin and Rimini). This is especially obvious in the case of Suburra, which was conceived simultaneously with the TV series (a coproduction between the American multinational Netflix and national Italian broadcaster RAI) to be released a couple of years later: the film therefore served as a sort of cinematic pilot for the show, which is in fact a prequel of both the original book and its adaptation for the screen. This example has often been indicated as the clearest sign of an 
industrial and aesthetic convergence between Italian film and television, which in recent years has led to the creation of a variety of films and TV series that were conceived from the beginning as part of a "dual" strategy, involving the production and distribution of different versions of the same projects via the two media (Barra and Scaglioni). Other films - I'm Not Scared (Io non ho paura, Gabriele Salvatores, 2004), My Brother is an Only Child, The Goodbye Kiss (Arrivederci amore ciao, Michele Soavi, 2006), Human Capital, La ragazza nella nebbia (Donato Carrisi, 2017) - are adaptations of non-serial bestsellers in Italy, all written by well-known writers and sometimes the recipients of important literary as well as film awards. Some of these books are real examples of crime fiction, while others are primarily linked to the genre because of the themes they explore (i.e., political violence, mafia, media representation of crime).

The notion "quality crime cinema" as described by Baschiera seems in fact perfectly suited to describe the majority of these films. ${ }^{8}$ As with their literary and television counterparts, they combine the thematic or generic elements of the crime genre with the marks of a certain kind of social realism, political commitment, and aesthetic ambition to acquire the cultural legitimacy that appears to be the necessary element to gain international visibility. By adopting the intermedial perspective proposed above, Locatelli's concept of "noirification" seems helpful in this context: while European film distributors, critics and scholars do not necessarily use the "noir" or "neo-noir" labels with the same nonchalance that we have noticed in the field of literature and television, that particularly broad use of the term could be easily applied to virtually all of the Italian crime films that have circulated abroad.

In fact, eleven of these titles are based on noir novels to highlight how, for this very reason, the national and international promotion of these films have certainly benefitted, even if indirectly, from the cultural legitimation - and the related commercial potential — of this label in the field contemporary popular fiction. In addition to the novels previously discussed, the case of I'm Not Scared is significant in this respect as it is an adaptation of a work by one of the most popular contemporary Italian noir writers, Niccolò Ammaniti, who has deeply influenced the development of the genre in fiction, film and television. The Goodbye Kiss is the adaptation of a novel written by the most important Italian proponent of the idea of "Mediterranean Noir", Massimo Carlotto, whose activitiy has been extremely important for the development of this label, in Italy and elsewhere (Jansen, Lanslots and Vermandere 89-154). Equally telling is the case of Paolo Virzi's adaptation of Stephen Amidon's novel Human Capital, originally set in Connecticut and turned into a noir film exploring the social and economic reality of Northern Italy. Donato Carrisi's La ragazza nella nebbia and Into the Labyrinth (2019) are also indicative of the same trend. The two novels from which they were adapted (by their own author) did not obtain the same critical legitimisation as other writers discussed here; however, Carrisi's move into the field of cinema immediately provided at least the first of them with the status of "quality", as La ragazza nella nebbia received four prizes at the most important national film awards - the David di Donatello - including the prize as the "Best Debuting Director". 9 .

The idea of "noirification", moreover, can help us identify other traits of these films that are specific to the fields of cinema and television. Almost all of the titles in this list that are not adaptations of noir novels can and indeed have been seen as instances of the approach to noir cinema typical of contemporary European art cinema or quality TV series. Sorrentino's The Consequences of Love, Placido's Angel of Evil (Vallanzasca: gli angeli del male, 2010), Sollima's A.C.A.B. (A.C.A.B. All Cops Are Bastards, 2012), Garrone's Dogman (2018), Carpignano's The Ciambra (A Ciambra, 2018), and the D'Innocenzo brothers' Boys Cry (La 
terra dell'abbastanza, 2018) clearly borrow at least some of the stylistic features of neo-noir, gangster films and/or TV series to insert themselves in these larger trends typical of contemporary film and television. Combining their more or less explicit authorial approach with these elements, they prove how it is possible to stress that a "noirification" specific to contemporary European cinema is also at work, and also in this sector it serves as an efficient tool to acquire the marks of "quality" that help the films obtain an international recognition.

As a matter of fact, if we compare the data about the transnational circulation of Italian crime films with that of Italian (anf European) films in general — which are still dominated by the figure of the director, international coproductions and a few unexpectedly successful comedies (Scaglioni 24-5) - we might argue that crime is perhaps the only popular genre that to some extent has contributed to the export of Italian films, even when this effort was not entirely satisfying. Confirming the same trend identified in the fields of fiction and television - and, of course, building directly and indirectly on their example-Italian cinema proves that the combination of some artistic ambition with the intermedial, commercial logic promoted by the crime genre has given shape to "quality" films that might potentially compete on the continental market. Rather than evaluating the absolute number of the circulation of these films outside of the country in purely quantitative terms, it seems more useful to look at the crime genre from an intermedial perspective and to insert the performance at the box office in the larger process of transmedia and transnational circulation of crime narratives.

\section{Conclusion}

In this article I have engaged with the research conducted in the frame of the DETECt project on the production and circulation of crime narratives in different media to assess whether and how European crime cinema contributes to the shaping of new, transnational and transcultural popular culture. Looking at data about the circulation of Italian crime films, it is possible to understand the specificity of cinema's role in this context, identifying both the limited reach of theatrical distribution on a transnational level and the impact of the authorial approach on the films' ability to fully participate in mainstream popular culture. In spite of these issues, the article has emphasised how an intermedial approach shows that contemporary European crime narratives have become more and more central in many creative industries precisely as a result of a process of cultural legitimisation, and how it is exactly as a result of this phenomenon that they have found increasingly wider opportunities to cross national borders.

The notion of "noirification" has been used in this sense to highlight how it is precisely through the adoption of a notion of "quality" that European crime narratives are gradually getting more attention by mainstream creatives, producers as well as critics, and are currently reaching larger transnational audiences than in previous decades. As a complex and contradictory phenomenon, the adoption of the themes and the stylistic features of noir to promote these works from both a cultural and a commercial point of view cannot but lead to a variety of approaches and results, largely depending on the specific media with which they engage and national contexts from which and to which they travel. On the one hand, the process of legitimation inevitably implies that the genre could reduce its ability to speak to a mass audience, often targeting primarily the educated urban middle classes or, in the case of cinema, the niche audience of hardcore cinephiles. On the other hand, a significant number of European crime novels, films and TV series have proven able to combine their ambitious thematic and stylistic features with the relatively successful attempt to capture an international public. Whether this trend will further consolidate and strengthen the European nature of these 
phenomena is arguably a question for the future. Whatever the case, it might be helpful to remark that these phenomena somehow parallel the current state of European cultural integration: if popular culture has contributed to increase the opportunities for cultural encounters among citizens across the continent, it is clear that this process has been largely uneven and is marked by many dramatic ambiguities as well as serious resistances.

\begin{tabular}{|c|c|c|c|c|c|}
\hline & Title & Director & Year & IMDb genre labels & $\begin{array}{l}\text { Non-domestic } \\
\text { admissions }\end{array}$ \\
\hline 1 & Gomorra & Matteo Garrone & 2008 & crime drama & $1,749,093$ \\
\hline 2 & Mio fratello è figlio unico & Daniele Lucchetti & 2007 & comedy crime drama & 460,759 \\
\hline 3 & Romanzo criminale & Michele Placido & 2005 & crime drama & 415,427 \\
\hline 4 & II traditore & Marco Bellocchio & 2019 & biography crime drama & 401,049 \\
\hline 5 & Dogman & Matteo Garrone & 2018 & crime drama thriller & 354,497 \\
\hline 6 & lo non ho paura & Gabriele Salvatores & 2004 & crime drama mystery & 349,891 \\
\hline 7 & Il capitale umano & Paolo Virzì & 2013 & crime drama & 328,634 \\
\hline 8 & Le conseguenze dell'amore & Paolo Sorrentino & 2004 & crime drama romance & 197,823 \\
\hline 9 & La ragazza nella nebbia & Donato Carrisi & 2017 & crime drama mystery & 158,668 \\
\hline 10 & La paranza dei bambimi & Claudio Giovannesi & 2019 & crime drama & 98,814 \\
\hline 11 & Suburra & Stefano Sollima & 2015 & action crime thriler & 97,618 \\
\hline 12 & I cento passi & Marco Tullio Giordana & 2002 & biography crime drama & 73,717 \\
\hline 13 & Vallanzasca: gli angeli del male & Michele Placido & 2010 & biography crime drama & 56,396 \\
\hline 14 & Anime nere & Francesco Munzio & 2015 & crime drama & 46,007 \\
\hline 15 & A Ciambra & Jonas Carpignanop & 2018 & crime drama & 43,617 \\
\hline 16 & Arrivederci amore ciao & Michele Soavi & 2006 & crime drama thriller & 36,657 \\
\hline 27 & La doppia ora & Giuseppe Capotondi & 2009 & crime drama mystery & 30,784 \\
\hline 18 & Romanzo di una strage & Marco Tullio Giordana & 2012 & crime drama mystery & 27,042 \\
\hline 19 & Smetto quando voglio & Sidney Sibilla & 2014 & comedy crime & 25,433 \\
\hline 20 & La terra dell'abbastanza & Damiano e Fabio D'Innocenzo & 2018 & crime drama & 19,418 \\
\hline 21 & La prima linea & Renato De Maria & 2009 & biography crime drama & 15,217 \\
\hline 22 & 5 è il numero perfetto & Igor Tuveri & 2019 & crime drama thriller & 13,690 \\
\hline 23 & La mafia uccide solo d'estate & PIF & 2013 & comedy crime drama & 13,265 \\
\hline 24 & A.C.A.B. & Stefano Sollima & 2012 & action crime drama & 11,512 \\
\hline
\end{tabular}

Table 1: Films tagged as "crime" on IMDb, with data about non-domestic theatrical admission from the LUMIERE database.

\section{Acknowedgement}

The research presented here has been financed by the research project DETECt - Detecting Transcultural Identity in European Popular Crime Narratives (Horizon 2020, 2018-2021) [Grant agreement number 770151].

\section{Notes}

${ }^{1}$ DETECt - Detecting Transcultural Identity in European Popular Crime Narratives (Horizon 2020, 2018-2021).

${ }^{2}$ In addition to his scholarly articles, Migozzi has published his quantitative analysis of this process on the portal of DETECt project (“Authors").

${ }^{3}$ Of course, many exceptions prove not only that a certain number of crime writers had already acquired a higher cultural status, but also that specific crime stories as well as the genre as a whole had been analysed by some of the most influential intellecturals of the twentieth century (from Eliot to Shklovsky, from Benjamin to Auden, from Kracauer to Eco, from Caillos to Lacan). And yet, the mainstream cultural system as a whole, and literary studies in particular, had largely regarded crime narratives as little more than pure, ephemeral entertainment. This 
approach only started to change substantially between the 1980s and 1990s, for instance in France (Gorrara) and Italy (Jansen, Lanslots and Vermandere 10-1; Pieri 4).

${ }^{4}$ On the concept of "quality" cinema in relation to European cinema see Wood.

${ }^{5}$ The number of films included in the list is not entirely reliable; it also comprises works that have never been completed, are still in production or have never been released, at least in the theatrical circuit.

${ }^{6}$ While the potential of digital distribution is apparent and might be better exploited in the future, studies on the accessibility of Italian films on international TV and digital platforms seems to suggest that it is still extremely limited (Barra and Perrotta).

${ }^{7}$ On the essential role of festivals, the critics and their cultural legitimation for the transnational circulation of Italian cinema in general see Scaglioni's edited collection and, in particular, the chapter authored by Garofalo and Morreale.

${ }^{8}$ Dom Holdoway has examined the specific case of Italian "quality" mafia films in a special issue of Comunicazioni sociali edited by Bisoni, Hipkins, and Noto, which explores the production, distribution and reception of Italian "quality" cinema more broadly.

${ }^{9}$ It would be also interesting to highlight here the case of La ragazza del lago (Andrea Maioli, 2007) — which is not included in this list only because IMDb categorises it as "drama mystery thriller" and which could be seen as an example of "Italian Nordic Noir", being the adaptation of the Norwegian novel Don't Look Back, written by Karin Fossum in 1996. The film, in any case, only sold 14,933 tickets at the international box office, according to LUMIERE data.

\section{References}

A.C.A.B [A.C.A.B. All Cops Are Bastards]. Directed by Stefano Sollima, Cattleya/Babe Film/Rai Cinema, 2012.

Agger, Gunhild. "Fiction of Europe." Nordicom Review, vol. 22, no. 1, 2001, pp. 43-55. https://doi.org/10.1515/nor-2017-0343.

Amidon, Stephen. Human Capital. Farrar, Strauss and Giroux, 2004.

Angel of Evil [Vallanzasca: gli angeli del male]. Directed by Michele Placido, Cosmo Produzioni/Babe Film/Fox International Pictures, 2010.

“Authors.” DETECt. www.detect-project.eu/portal/authors. Accessed 6 January 2022.

Baetens, Jan, and Fred Truyen. "From Euro-noir to Europe." European Review, vol. 29, no. 5, Oct. 2021, pp. 1-4. https://doi.org/10.1017/S1062798720001179. 
Baetens, Jan, Ana Schultze, and Fred Truyen. "Donald Westlake's Ordo: Not Euro, not Noir, but Euro-Noir?" European Review, vol. 29, no. 5, Oct. 2021, pp. 19. https://doi.org/10.1017/S1062798720001180.

Babylon Berlin. Created by Henk Handloegten, Tom Tykwer, and Achim von Borries, Sky, 2017-.

Barra, Luca, and Marta Perrotta. "Il cinema italiano all'estero nelle finestre secondarie. Televisione, piattaforme digitali e convergenza." Cinema italiano made in Italy, edited by Massimo Scaglioni, Carocci, 2020, pp. 95-112.

Barra, Luca, and Massimo Scaglioni. "One Story, Two Media: Strategies and Intended Audiences in Italian Productions for Cinema and Television." Comunicazioni sociali, no. 3, Sept.-Dec. 2016, pp. 412-25.

Baschiera, Stefano. "European Crime Cinema and the Auteur." European Review, vol. 29, no. 5, 2021, pp. 588-600. https://doi.org/10.1017/S1062798720001143.

Benvenuti, Giuliana. Il brand Gomorra: dal romanzo alla serie TV. Il Mulino, 2017.

Biscarrat, Laetitia, and Alice Jacquelin. "Impossible Euronoir? Le polar européen dans sa réception critique française.” ¿Interrogations?, no. 32, June 2021, http://www.revueinterrogations.org/Impossible-Euronoir-Le-polar. Accessed 31 July 2020.

Bisoni, Claudio, Danielle Hipkins, and Paolo Noto (eds). Comunicazioni sociali, no. 3, "Italian Quality Cinema: Institutions, Taste, Cultural Legitimisation”, Sept.-Dec. 2016.

Black Souls [Anime nere]. Directed by Francesco Munzi, Cinemaundici/Babe Film/Rai Cinema, 2014.

Boni, Marta. Romanzo criminale: Transmedia and Beyond. University Ca' Foscari, 2013.

Bondebjerg, Ib, and Eva Novrupp Redvall (eds.). European Cinema and Television: Cultural Policy and Everyday Life. Palgrave Macmillan, 2015.

Bondebjerg, Ib, et al. Transnational European Television Drama: Production, Genres and Audiences. Palgrave Macmillan, 2017.

Boys Cry [La terra dell'abbastanza]. Directed by Damiano and Fabio D'Innocenzo, Pepito Produzioni/Rai Cinema, 2018.

Breaking Bad. Created by Vince Gilligan. AMC, 2008-2013.

Buonanno, Milly. "Italian TV drama: The Multiple Forms of European Influence." European Cinema and Television: Cultural Policy and Everyday Life, edited by Eva Novrup, Ib Bondebjerg, and Andrew Higson, Palgrave MacMillan, 2015, pp. 195-213.

Carrisi, Donato. La ragazza nella nebbia. Longanesi, 2015. 
---. L'uomo del labirinto. Longanesi, 2017.

The Ciambra [A Ciambra]. Directed by Jonas Carpignano, Stayblack Productions/Rai Cinema, 2017.

The Consequences of Love [Le conseguenze dell'amore]. Directed by Paolo Sorrentino, Fandango/Indigo Film/Medusa Film, 2004.

Creeber, Glen. "Killing Us Softly: Investigating the Aesthetics, Philosophy and Influence of Nordic Noir Television." The Journal of Popular Television, vol. 3, no. 1, 2015, pp. 2135. https://doi.org/10.1386/jptv.3.1.21_1.

Dall'Asta, Monica, Natcha Levet, and Federico Pagello. "Glocality and Cosmopolitanism in European Crime Narratives." Academic Quarter, vol. 22, Spring 2021, pp. 1-18. https://doi.org/10.5278/ojs.academicquarter.vi22.6598.

Damrosch, David, Theo d'Haen, and Louis Nilsson (eds). Crime Fiction as World Literature. Bloomsbury Academic, 2017.

Dark. Created by Baran bo Odar and Jantje Friese, Netflix, 2017-2020.

De Luca, Giovanna. "From Fear to Laughter: How Comedy Came to Portray the 'Camorra' in Contemporary Italian Film.” Italica, vol. 95, no. 3, Fall 2018, pp. 400-416.

Dexter. Created by James Manos Jr., Showtime, 2006-2013.

Dobrescu, Caius. "Failed Cultural Hybridity and Takeaways for the Euro-Noir in the American-Romanian Series Comrade Detective." Academic Quarter, vol. 22, Spring 2021, pp. 1-17. https://doi.org/10.5278/ojs.academicquarter.vi22.6609.

Dogman. Directed by Matteo Garrone, Archimede/Le Pacte/Rai Cinema, 2018.

Dyer, Richard, and Ginette Vincendeau. Popular European Cinema. Routledge, 1992.

Eleftheriotis, Dimitris. Popular Cinemas of Europe: Studies of Texts, Contexts, and Framework. Continuum, 2001.

Fargo. Created by Noah Hawley, FX, 2014-.

Fossum, Karin. Don't Look Back. Harcourt, 2002.

Garofalo, Damiano, and Emiliano Morrreale. "Il cinema italiano all'estero e la sua legittimazione culturale: i festival e la critica specializzata." Cinema made in Italy, edited by Massimo Scaglioni, Carocci, 2020, pp. 77-93.

The Girl With a Dragon Tatoo [Män som hatar kvinnor]. Directed by Niels Arden Oplevl, Yellow Bird, 2009. 
Gomorrah [Gomorra]. Directed by Matteo Garrone, Fandango/Rai Cinema, 2008.

Gomorrah [Gomorra: la serie]. Created by Leonardo Fasoli, Stefano Bises, and Roberto Saviano, Sky, 2014-.

The Goodbye Kiss [Arrivederci amore ciao]. Directed by Michele Soavi, 2006.

Gorrara, Claire. "French crime fiction: From genre mineur to patrimoine culturel." French Studies, vol. 61, no. 2, April 2007, pp. 209-14. https:///doi.org/10.1093/fs/knl216.

Guerra, Michele, Sara Martin, and Stefania Rimini (eds.). Universo Gomorra: da libro a film, da film a serie. Mimesis, 2019.

Forshaw, Barry. Euro Noir: The Pocket Essential Guide to European Crime Fiction, Film \& $T V$. Pocket Essentials, 2014.

Hansen, Kim Toft. "From Nordic Noir to Euro Noir: Nordic Noir Influencing European Serial SVoD Drama." Nordic Noir, Adaptation, Appropriation, edited by Linda Badley, Andrew Nestingen \& Jaakko Seppälä, Palgrave Macmillan, 2020.

Hansen, Kim Toft, Steven Peacock, and Sue Turnbull (eds.). European TV Crime Drama and Beyond. Palgrave Macmillan, 2018.

Hill, Annette, and Sue Turnbull. "Nordic Noir." Oxford Research Encyclopedia of Criminology, 2016, pp. 1-21. http://dx.doi.org/10.1093/acrefore/9780190264079.013.294.

Holdoway, Dominic. "Boss in sala: Cultural Legitimacy and Italian Mafia Films." Comunicazioni sociali, 2016, no. 3, pp. 445-54.

Human Capital [Il capitale umano]. Directed by Paolo Virzì, Indiana Production/Motorino Amaranto/Rai Cinema, 2013.

Huw, David Jones. “The Production, Distribution and Reception of Italian Quality: The Case of Cultural Interest." Comunicazioni sociali, 2016, no. 3, pp. 361-74.

I'm Not Scared [Io non ho paura]. Directed by Gabriele Salvatores, Colorado Film Production/Cattleya, 2003.

In Bruges. Directed by Martin MacDonagh, Focus Features/Film 4/Blueprint Pictures, 2008.

Jacquelin, Alice. "Genèse et circulations d'un genre populaire en régime médiatique: le cas du Country Noir.” Belphégor, vol. 19, no. 1, 2021. https://doi.org/10.4000/belphegor.3803.

Jansen, Monica, Inge Lanslots, and Dieter Vermandere (eds.). Memoria in Noir: un'indagine pluridisciplinare. Peter Lang, 2011. 
Kalai, Sándor, and Anna Keszeg. "Is There Such a Thing as Hungarian Nordic Noir?: Cultural Homogeneization and Glocal Agency." Academic Quarter, no. 22, 2021. https://doi.org/10.5278/ojs.academicquarter.vi22.6600.

Locatelli, Massimo. Psicologia di un'emozione. Thriller e noir nell'età dell'ansia. Vita \& Pensiero, 2017.

Migozzi, Jacques. "Crime Fiction Import/Export in European Publishing: The Emergence of Euro Noir through the Process of Translation." Academic Quarter, 22, Spring 2021, doi: https://doi.org/10.5278/ojs.academicquarter.vi22.6599.

Mondello, Elisabetta. Roma noir 2007. Luoghi e nonluoghi nel romanzo nero contemporaneo. Robin, 2007.

Money Heist [La casa de papel]. Created by Álex Pina. Antena 3/Netflix, 2017.

My Brother Is an Only Child [Mio fratello è figlio unico]. Directed by Daniele Lucchetti, Cattleya/Babe Film, 2007.

One Hundred Steps [I cento passi]. Directed by Marco Tullio Giordana, Rai Cinema/Tele+/ Titti Cinema, 2002.

Ozark. Created by Bill Dubuque and Mark Williams, Netflix, 2017-.

Pagello, Federico. "Dal giallo al noir. Glocalismo, transculturalità e transmedialità nel poliziesco italiano contemporaneo". MediAzioni, vol. 28, 2020, pp. 30-47.

---. "Images of the European Crisis: Populism in Contemporary European Crime TV Series." European Review, vol. 29, no. 5, Oct. 2021, pp. 1-14. https://doi.org/10.1017/S1062798720001167.

Peaky Blinders. Created by Steven Knight, BBC2/BBC1, 2013-.

Pepper, Andrew. "The Problem of Mediterranean Noir." Paper presented at the DETECt international conference Detecting Europe in Contemporary Crime Narratives, Link Campis University, 21 June 2021.

Pezzotti, Barbara. "Mediterranean Identity in European Crime Fiction." Paper presented at the DETECt international conference Detecting Europe in Contemporary Crime Narratives, Link Campis University, 21 June 2021.

Pieri, Giulia. Italian Crime Fiction, Wales UP, 2011.

Piranhas [La paranza dei bambini]. Directed by Claudio Giovannesi, Palomar/Vision Distribution, 2019.

A Prophet [Un prophète]. Directed by Jacques Audiard, Why Not Productions, 2013. 
La ragazza nella nebbia. Directed by Donato Carrisi, Colorado Film Production/Medusa Film, 2017.

The Returned [Les Revenants]. Created by Fabrice Gobert, Canal+, 2013-2015.

Romanzo criminale. Directed by Michele Placido, Cattleya/Babe Film/Warner Bros/Aquarius Films, 2005.

Scaglioni, Massimo. Cinema Made in Italy: La circolazione internazionale dell'audiovisivo italiano. Carocci, 2020.

Sherlock. Created by Mark Gatiss and Steven Moffat, BBC, 2010-.

The Sopranos. Created by David Chase, HBO, 1999-2007.

Spicer, Andrew. European Film Noir, Edinburgh UP, 2007.

Steenberg, Lindsay. "The Fall and Film Noir." Critical Studies in Television, vol. 18, no. 1, 2016, pp. 58-75. https://doi.org/10.1177/1527476416664185.

Suburra. Directed by Stefano Sollima, Cattleya/Rai Cinema, 2015.

The Traitor [Il traditore]. Directed by Marco Bellocchio, IBC Movie/Rai Cinema, 2019.

True Detective. Created by Nic Pizzolatto, HBO, 2013-.

Turnaturi, Gabriella. "The Invention of Mediterranean Noir." New Perspectives in Italian Cultural Studies: The Arts and History, edited by Graziella Parati, vol. 2, The Arts and Histories, Fairleigh Dickinson UP, 2012, pp. 53-71.

Victoria. Directed by Sebastian Schipper, Monkey Boy/Radical Media, 2015.

Wood, Mary P. Contemporary European Cinema. Hodder Arnold, 2007.

\section{Suggested Citation}

Pagello, Federico. "DETECting the 'Noirification' of European Popular Narratives Across Film, Fiction and Television." Alphaville: Journal of Film and Screen Media, no. 22, pp. 1430. https://doi.org/10.33178/alpha.22.01.

Federico Pagello is Lecturer in Film and Media Studies at D'Annunzio University in ChietiPescara, Italy. Together with Monica Dall'Asta he has designed and coordinated the DETECt project. His research interests include the transnational circulation of European popular culture, transmedia serial narratives, and film theory. He is the author of two monographs: Grattacieli e superuomini. L'immagine della città fra cinema e fumetto (Le Mani, 2010), Quentin Tarantino and Film Theory: Aesthetics and Dialectics in Late Postmodernity (Palgrave Macmillan, 2020). 